\title{
Mit kíván a (felsőoktatási) könyvtár?
}

\section{Bevezetö}

A felsőoktatási könyvtárak sajátos környezetben müködnek. Egyfelől érvényesek rájuk az általános társadalmi, gazdasági, technológiai hatások, másfelől a tudományos tevékenység és a felsőoktatás dimenzióiban kell helytállniuk. Versenytársaik a nemzetközi és a hazai tudományos szakkönyvtárak, illetve az információszolgáltató intézmények, vállalatok, platformok.

A környezeti tényezők rendkívül gyorsan változnak, ezért a könyvtáraknak évente felül kell vizsgálniuk a stratégiájukat, és alkalmazkodniuk kell az újabb és újabb kihívásokhoz. Vajon a könyvtárosképzés tudja-e követni a felsőoktatási könyvtárak szakemberei iránt támasztott követelményeket? Felvértezettek-e a ma végzett könyvtárosok, rendelkeznek-e a szükséges kompetenciákkal? Elegendő-e a könyvtárosképzés által nyújtott tudás és gyakorlat? Milyen más képzési lehetőségek egészíthetik ki a könyvtárosok felkészültségét, hogy ezen a területen versenyképes tudást tudjanak felmutatni?

Ahhoz, hogy ezekre a kérdésekre választ kapjunk, megvizsgáljuk a felsőoktatásra és a felsőoktatási könyvtárakra érvényes legfontosabb trendeket, és áttekintjük az Egyetemi Könyvtárigazgatók Kollégiuma által végzett, a könyvtárosok kompetenciaigényeiről szóló felmérés eredményeit. A visszajelzésekből kitünik, hogy a felsőfokú informatikus könyvtáros szakképzésböl kikerülö pályakezdők esetében a belépés után még komoly saját erőből történő kompetenciafejlesztés szükséges. Fel szeretnénk hívni a figyelmet arra, hogy a képzésnek követnie kell az elmúlt években a szakterületen zajlott paradigmaváltást, valamint arra, hogy a tudás és a kompetenciák fejlesztése folyamatos feladat az intézmények vezetői számára is. 


\section{Trendek a felsőoktatásban és a felsőoktatási könyvtárakban}

2.1. Trendek a felsőoktatásban ${ }^{1}$

- Egyre komplexebbé váló változásokkal, a technológiai fejlődés felgyorsulásával kell számolni.

- A társadalmi változások közül a népességnövekedés, az életkor kitolódása, a migráció és a társadalmi konfliktusok növekedése egyaránt hatást gyakorol.

- A gazdaság változásának hatásai: a szolgáltató szektor növekedése, a tudásalapú gazdaság térnyerése, az új gazdasági ágazatok kialakulása, a felsőoktatás piacosodása, gazdasági szereplők megjelenése a felsőoktatásban.

- A felsőoktatási kínálat átalakulása: új intézménytípusok, új diplomát adó intézmények jelennek meg, erősödik a magánoktatás, a képzési programok sokfélesége válik jellemzővé.

- Az intézményi kultúra változása: elvárás a minőség- és teljesítménymenedzsment, megjelenik a teljesítményalapú finanszírozás.

- Nemzetközi verseny: nemzetközi felsőoktatási hálózatok alakulnak ki, a felsőoktatás exportcikként jelenik meg.

- Technológia fejlődés: a tanulást támogató technológiák fejlődésével párhuzamosan a mesterséges intelligencia is teret nyer.

- A hallgatók összetételének sokfélesége: idősebb/felnőtt hallgatók, új társadalmi csoportok, heterogén kulturális összetétel jelenik meg.

- Az oktatás változásai: kompetenciaalapú oktatás, valós, gyakorlati feladatokkal való találkozás, rugalmas képzési struktúra, tanulásmenedzsment rendszerek alkalmazása.

- Kutatási környezet: nyílt hozzáférésủ tudomány, a kutatási eredmények és adatok közzététele támogatási feltétellé válik.

A felsőoktatásra hatást gyakorló trendek új kompetenciák megjelenését vonják maguk után:

- nagyszámú adathalmaz kezelése, feldolgozása, kritikai elemzése,

- más kultúrákból érkezőkkel való együttmüködés,

${ }^{1}$ A fejezethez felhasznált irodalom: Halász Gábor: A felsőoktatás globális trendjei és szakpolitikai válaszok az OCD országokban és az Európai Unióban. Prezentáció. https://www.slideshare. net/fmik_ppk_elte/a-felsoktats-globlis-trendjei-s-szakpolitikai-vlaszok-az-oecd-orszgokban-s-azeurpai-uniban-halsz-gbor (2019. augusztus 27.); Márton Alexandra: A felsőoktatás jövője: globális trendek, forgatókönyvek, dilemmák és megoldások 2030-ban. MA/MSc szakdolgozat. BCE Gazdálkodástudományi Kar, Vezetés és Szervezés Tanszék. 2017. http://szd.lib.uni-corvinus.hu/10684 (2019. augusztus 27.); Hrubos Ildikó: Felsőoktatás-politika: Európai trendek a felsőoktatásban a XXI. század első évtizedében. https://regi.tankonyvtar.hu/hu/tartalom/tamop425/0010_2A_06_ Hrubos_Ildiko_A_felsooktatas-politika_Europai_trendek_a_felsooktatasban_a_XXI_szazad_ elso/index.html (2019. augusztus 27.) 
- a saját tudás folyamatos fejlesztése,

- a mesterséges intelligencia terjedése mellett felértékelödnek olyan emberi tulajdonságok, mint a kreativitás, innovativitás, az erkölcsi értékek, a felelős polgár kívánalma, a környezet megóvása.

2.2. Trendek és stratégia a felsőoktatási könyvtárakban ${ }^{2}$

A felsőoktatásra ható változások, az információhoz való hozzáférés és a szolgáltatásokkal kapcsolatos igények, a kulturális örökség hozzáférhetővé tétele, a tudás hasznosításának társadalmi elvárása új trendek számbavételét követeli meg a könyvtárak stratégiájának kialakításakor. A kiemelt trendek a következők:

- intézményi digitális archívumok létrehozása (a tudásvagyon kezelése),

- több adatbázisban egyidejü keresés (discovery szolgáltatás),

- személyre szabott tanulási környezet biztosítása,

- a könyvtár: információs, képzési, technológiai szolgáltató központ,

- oktatási és tanulási menedzsmentrendszerek kezelése, tömeges nyílt online kurzusok, elektronikus tananyagok webkönyvtára, webináriumok, streamszerver,

- online kurzusok (MOOC, webinárium),

- e-könyvkiadás,

- kutatástámogatás, kutatási eredményekhez való hozzáférés,

- a kulturális örökség digitális megőrzése, disszeminációja,

- az Open Science-mozgalom támogatása,

- digitális írástudás fejlesztése: a lemorzsolódás csökkentése,

- új munkamódszerek (szervezeti kultúra): munkacsoport (teammunka, projekt), hálózati együttmüködés,

- az egymástól tanulás támogatása (használók bevonása, crowdsourcing).

A fenti trendekre válaszolt a magyar felsőoktatási könyvtárak szakmai szervezete, az Egyetemi Könyvtárigazgatók Kollégiuma, amikor megalkotta jövőképét:

„A felsőoktatási könyvtárak a 2020-as évek elején:

- egy dinamikusan fejlődő és teljesítményelvű felsőoktatás, valamint a hazai és nemzetközi viszonylatban hálózatosodó tudományos kutatási és innovációs intézményrendszer kulcsszereplöi;

- szabványokon alapuló digitális gyüjtemények építésével és müködtetésével vezető szerepet játszanak a tudományos eredmények hosszú távú megőrzésében és nemzetközi disszeminációjában;

${ }^{2}$ A fejezet az alábbi dokumentum alapján készült: Antal Istvánné - Karácsony Gyöngyi Kálóczi Katalin - Keveházi Katalin - Nagy Zsuzsanna: A felsőoktatási könyvtárak stratégiai irányai 2018-2013: az Egyetemi Könyvtárigazgatók Kollégiumának javaslata. https://ekk.org.hu/ wp-content/uploads/2020/08/EKFJ_2018_2023a.pdf (2019. augusztus 27.) 
- az innovatív tudományos kommunikáció, a nyitott tudomány és a nyílt hozzáférés előmozdításával segítik a magyar tudomány nemzetközi versenyképességének növelését;

- a digitális készségek és szolgáltatások fejlesztésének hálózati csomópontjai az egyetemi közösségek és - harmadik missziójuk keretében - az állampolgárok számára egyaránt;

- a transzverzális készségek fejlesztését célzó képzési programjaik és személyre szabott szolgáltatásaik révén támogatják a tudásátadást, illetve képessé teszik a tudományos közösség tagjait, köztük a hallgatókat is felelősségteljes új tudás létrehozására és ennek disszeminációjára;

- széles spektrumú szolgáltatásaik és korszerü információs technológiával felszerelt tanulási és közösségi tereik révén hozzájárulnak a hallgatói eredményességhez, egyúttal növelik a felsőoktatási intézmények aktivitását a társadalmi kihívások kezelésében és a társadalmi innováció terjesztésében;

- a nyomtatott és digitális nemzeti kulturális örökség hozzáférhetővé tételének és megőrzésének megkerülhetetlen szereplöi."

A stratégiai dokumentum a célok elérését a humánerőforrás fejlesztésével, a korszerű vezetési és szervezeti kultúra kialakításával a tudatos kommunikáció és minőségmenedzsment révén javasolja elérni.

\section{Képzés és kompetenciafejlesztési igények. Felmérés a felsőoktatási könyv- tárak körében ${ }^{3}$}

A felsőoktatási rendszer fejlesztési céljainak (teljesítményelvü oktatási-tanulási környezet, világszínvonalú kutatás) megvalósítása nem képzelhető el megfelelően képzett, elhivatott, az előrevetített kultúrát magáénak valló, fejlődőképes támogató személyzet nélkül. A felsőoktatási könyvtárak kiemelt stratégiai területe a könyvtári dolgozók kompetenciafejlesztése, a megfelelően képzett humánerőforrás biztosítása, az alkalmazkodó szervezeti kultúra kialakítása és menedzsmenteszközök integrálása az intézményekben.

A képzés-kompetenciafejlesztés témájára irányuló felmérés kisebb része kvantitatív, jelentősebb hányada kvalitatív tényezőkre irányult. Arra kerestük a választ, hogy a rendkívül heterogén magyar felsőoktatási könyvtári környezetben kirajzolódnak-e olyan hasonlóságok, különbségek vagy jellemzők, melyek a jövőre nézve a szakember-utánpótlás, a képzés és kompetenciafejlesztés irányainak, illetve a szükséges intézkedéseknek a meghatározásában segítségünkre lehetnek.

Az Egyetemi Könyvtárigazgatók Kollégiuma tagintézményeinek kiküldött kérdőívet egyetlen kivétellel minden intézmény visszajuttatta, így a fel-

\footnotetext{
${ }^{3}$ A fejezet az EMMI Felsőoktatásért Felelős Államtitkárságának felkérésére készített felmérés eredményeit ismerteti, amelyet az Egyetemi Könyvtárigazgatók Kollégiuma végzett el 2019-ben.
} 
dolgozott kérdőívek száma összesen 35. Többször említésre került, hogy az egyetemi könyvtárak, illetve az egyetemi könyvtári hálózat szerkezete intézményenként eltérő. Ezt a tényt - környezeti elemzés hiányában - a teljes felmérés során adottságként kezeltük.

A vizsgált intézmények dolgozói létszáma összesen 921 fö. A létszám szerinti rangsort 5 nagy könyvtár (DEENK, SZTE Klebelsberg Könyvtár, PTE Egyetemi Könyvtár, BME OMIKK, ELTE Egyetemi Könyvtár és Levéltár) vezeti, 50 feletti munkatársi állománnyal. Öket 21 olyan könyvtár követi, melynek személyi állománya 10 és 32 fő közötti. A sort 9 , legfeljebb 9 fövel müködő felsőoktatási könyvtár zárja (1. ábra).

A dolgozók életkora tekintetében haranggörbét tudunk kimutatni: $80 \%$-uk 30 és 60 év közötti, a fennmaradó 20\%-ot körülbelül egyenlő arányban a 60 év fölöttiek, illetve a 30 év alattiak teszik ki. A munkatársak 79\%-a több mint 3 éve dolgozik a könyvtárban, 57\%-uk jelenlegi munkaviszonya 10 évnél is hosszabb. A felsőoktatási könyvtárak dolgozóinak 74\%-a nö. Az egyes intézmények között releváns mintázatokat életkor, munkaviszony, nemi eloszlás tekintetében nem tudtunk kimutatni.

Az állomány $12 \%$-a dolgozik vezető beosztásban, a 2 vagy több vezetői beosztás a 13-nál magasabb létszámú intézményekben jelenik meg.

A dolgozók 82\%-a rendelkezik szakirányú könyvtári végzettséggel, akiknek közel a fele (a teljes minta 38\%-a) egyetemi szintü könyvtáros diplomát tud felmutatni. A könyvtáros képzettséggel nem rendelkező kollégák nagyobb része informatikus végzettségü.

A kvalitatív kérdések esetében feltételezhető, hogy a vezető személyisége, illetve a közvetlen környezet által állított követelmények (kihívások/lehetöségek, vagy azok hiánya) vezették a válaszadó tollát. Erre egy olyan kérdéspár világít rá, ahol az egyes munkakörök betöltéséhez szükséges végzettségről érdeklődtünk (7. Melyek azok a munkakörök a szervezetben, amelyekhez mindenképpen szakirányú végzettség szükséges? Illetve: 9. Milyen munkakörben tudja alkalmazni a nem könyvtáros diplomával rendelkezőket?). Számos jellegzetes könyvtári munkakör mindkét kérdésnél felsorolásra került. A nem szakképzettséghez kötött munkakörök között több olyan feladatkör jelenik meg, melyeket az újabb kihívások hívtak életre: humánerőforrás menedzsment, elektronikus tartalomkezelés, oktatás- és kutatástámogatás, digitális tartalomfejlesztés, e-learning, adatmenedzser, ismeretterjesztő, UX (user experience design), projektmenedzser (2. ábra). 


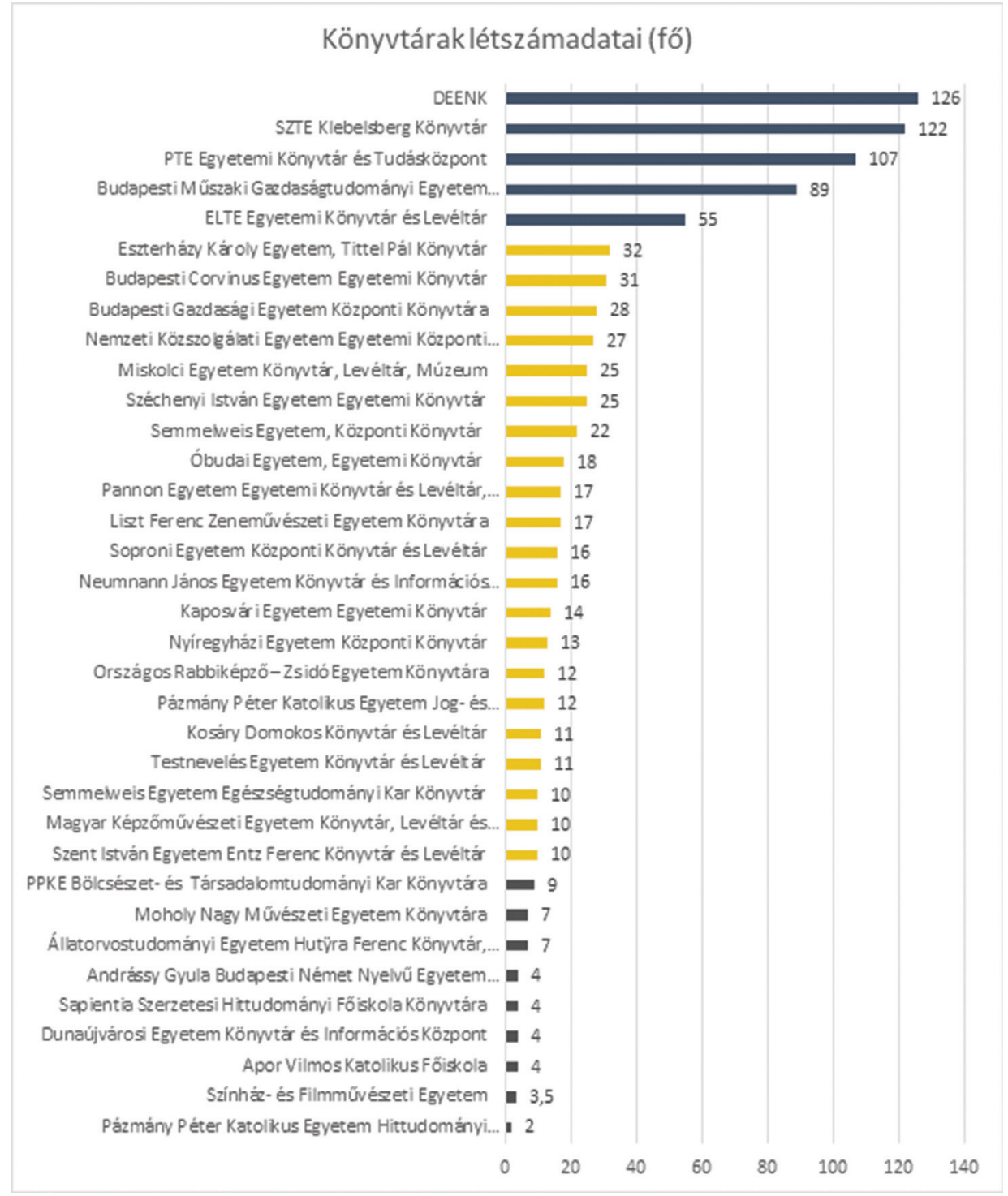

1. ábra. A felmérésben résztvevő könyvtárak létszámadatai 


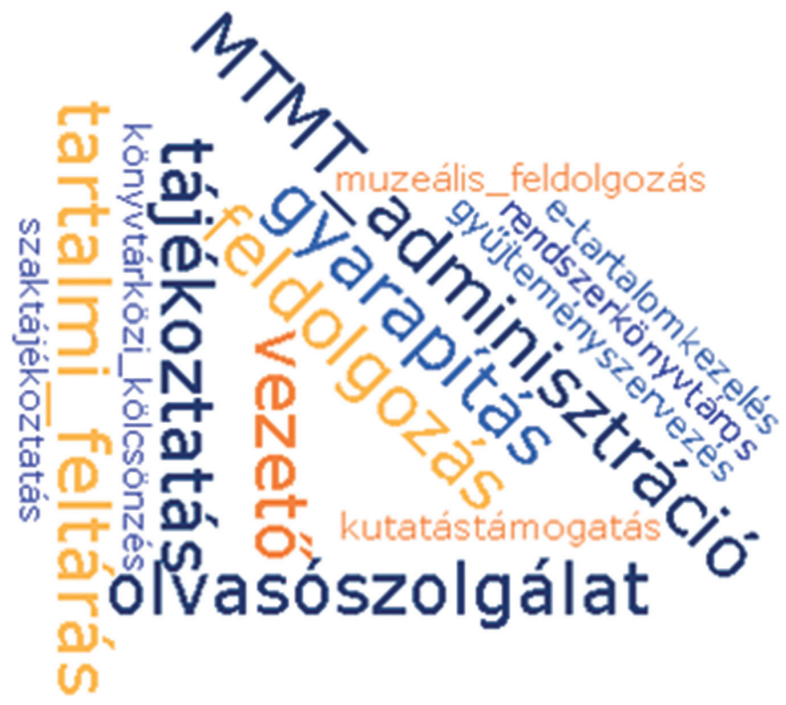

7. Melyek azok a munkakörök a szervezetben, amelyekhez mindenképpen szakirányú végzettség szükséges?

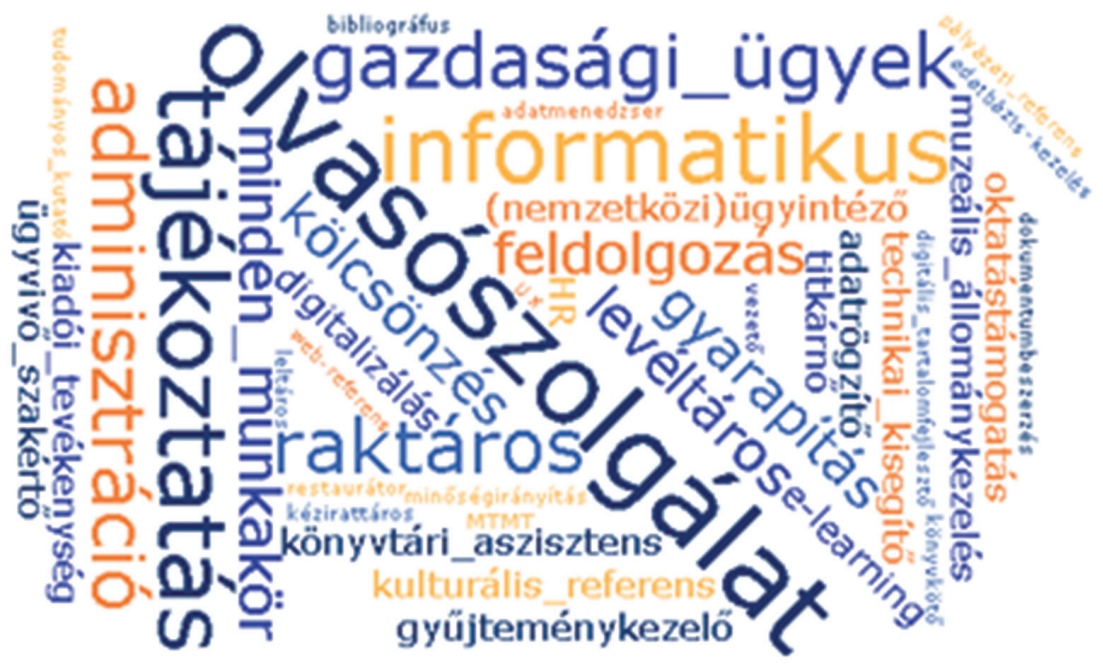

9. Milyen munkakörben tudja alkalmazni a nem kơmytáros diplomával rendelkezôket?

2. ábra. Könyvtáros végzettség és munkakörök 
A szóban forgó két kérdésre adott válaszokból kitünik, hogy számos olyan munkakör van, ahol nem hátrány, ha nincs a dolgozónak könyvtári végzettsége sőt, inkább jelentkezik hátrányként az egyéb kompetenciák hiánya, például bizonyos tudományterületek alapos ismerete. Ez leginkább a természettudományi és egészségtudományi területekre, illetve bizonyos társadalomtudományokra (pl. gazdaságtudomány, jog) lehet igaz. Itt az ezeknek megfelelö végzettség lenne elsődleges - különösen, ha némi kutatói tapasztalat és kapcsolatrendszer is van mögötte.

A vezetők többsége megfelelőnek tartja a dolgozók tudását és kompetenciáit. Néhányan említenek erős hiányosságokat is, aminek okaként forráshiányt, esetenként a motiváció-, vagy a kompetencia/képességek hiányát jelölik meg. A kollégák nagy többsége szívesen tanul, nyitott, és folyamatosan fejleszti magát. A vezetők tisztában vannak a folyamatos tanulás szükségszerüségével, külső és belső képzésekkel biztosítják a fejlődést.

Kisebb könyvtárakban előfordul, hogy a szakismeret, a tudományos felkészültség kiemelkedő, míg a könyvtárszakmai ismeretek fejlesztésre szorulnak. Esetenként korlátot szab a hiányos, nem frissülö informatikai, nyelvi ismeret, a továbbképzésekre fordítható források korlátozott volta, $\mathrm{s}$ nem utolsósorban szakmai tanulmányutak minimalizáltsága - ugyancsak forráshiány miatt. A hagyományos könyvtári környezet is állandó megújulást feltételez és igényel a korszerü kompetenciák alkalmazhatóságának, használatának vonatkozásában. Bizonyos jellemző kompetenciák fejlesztendők, például a nyelvtudás és az informatikai/digitális kompetenciák (többek között API-programozás és applikációfejlesztés), illetve olyan jellegü támogatás, melyekkel személyi tudásmenedzserekké, tudás-coachokká válhatnának a könyvtárosok. Ehhez pedig jobb pszichológiai-andragógiai felkészültségre is szükség lenne a klasszikus ügyfélbarát gondolkodás és elhivatottság mellett.

A közösségi média platformok kreatív használata is olyan digitális/kommunikációs kompetencia, amiből nincs elegendő jelenleg. Ebben a tekintetben a frissen végzett szakemberek tudása magabiztosabb, szélesebb spektrumú, míg az idősebb kollégák ezirányú kompetenciáinak fejlesztése időnként nehézkes. A visszajelzésekből kitünik, hogy a felsőfokú informatikus könyvtáros szakképzésből kikerülő pályakezdők esetében a belépés után még komoly saját erőből történő kompetenciafejlesztés szükséges.

Érdemes lenne megvizsgálni, hogy a képzés milyen mértékben követi az elmúlt években a szakterületen lezajlott paradigmaváltást, van-e rálátása az egyetemi könyvtári gyakorlatban szükséges ismeretkörre. A változás menedzselése, a nyitottság, a nyelvtudás a természetes fluktuációval javítható lenne, ha a frissen végzett könyvtárszakos hallgatók kompetenciái és kultúrája megfelelne az elvárásainknak. Gyakran tapasztaljuk, hogy a nem könyvtárszakos diplomával 
felvett (végzett vagy hallgatóként alkalmazott) fiatalok nyitottak, sokoldalúak, csapatmunkára, kreatív és rutin-feladatokra is jól alkalmazhatók.

Melyek azok a munkakörök, amelyek betöltése nehezen oldható meg a hiányzó kompetenciák miatt? Erre a kérdésre számos terület került megnevezésre, ami az egyszakos könyvtárosképzés olyan hiányosságára utal, amivel a hagyományos szaktájékoztatás is fenntarthatatlan, ugyanakkor a kutatás- és oktatástámogatás sem emelhetö rendszerszintre.

Több kérdésnél erősen jelentkezik az aktív (angol)nyelvismeret, továbbá olyan jogi és közgazdasági kompetenciák igénye, melyek a digitális korban elengedhetetlenek: szerzőijog-kezelési, adatvédelmi, továbbá a minőségbiztosítási folyamatokhoz szükséges mérési-elemzési- és statisztikai ismeretek, valamint a kommunikációs jártasság. A rendszerszemlélet, a HR és menedzsment ismeretek, az erőforrás-érzékenység az alacsonyabb vezetői szinten is fejlesztendő kategóriát alkotnak.

Milyen kompetenciák, ismeretek hiányoznak leginkább az egyetemi könyvtárakból? Ebben a kérdéskörben 19 felsorolt kompetenciát súlyoztak a válaszadók 1-6-ig egy skálán ( 6 = leginkább hiányzik). Az eredmény rendkívül szerteágazó véleményeket tükröz. A leginkább hiányzó kompetenciák közé a változásmenedzsment, valamint a PR és marketing került. Ezeket követi az időmenedzsment és feladatütemezés, a szóvivői és képviseleti készségek. Legalacsonyabb átlag-súlyt az alapvető (hagyományos) könyvtárszakmai ismeretek kapták. A szolgáltatáscentrikusság és ügyfélbarát gondolkodás a könyvtárszakmai kultúra alapvető értékei közé tartoznak, ezt visszaigazolja e két kategória alacsony átlaga is (3. ábra). Lehetőséget adtunk további hiányzó kompetenciák megnevezésére, melyek között említésre került az intézményi kommunikáció, a mobilitás, a munkafolyamat-szervezést segitő digitális eszközök használatának ismerete és azok használatához való affinitás, a logisztikai kompetenciák, a csapatban gondolkodás, illetve néhány speciális szaktudás és végzettség (marketing ismeretek és gyakorlat, hebraisztika, judaisztika, történelem, irodalom, vallástudomány, teológia, jogi ismeretek, gazdasági ismeretek).

A szervezet méretéből fakadóan a nagyobb könyvtáraknál jelennek meg hamarabb az attitüd-problémák, valamint hiányzó kompetenciaként a szolgáltatáscentrikusság, az ügyfélbarát gondolkodás és a motiváció. 


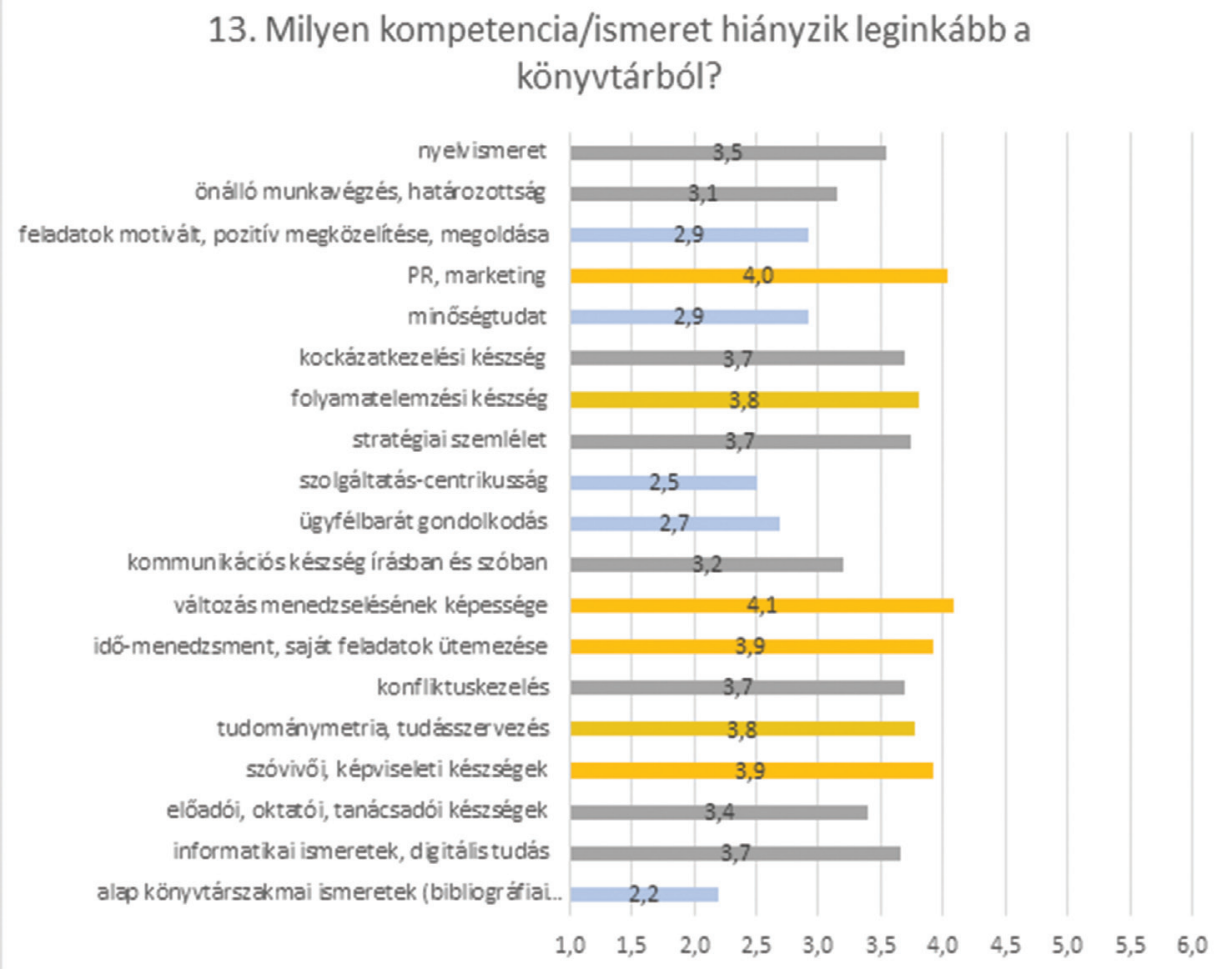

3. ábra. Hiányzó kompetenciák

A vezetői utánpótlás tekintetében jellemzően nincs kidolgozott stratégia. A könyvtár vezetői nyomon követik a munkatársak feladatvégzését, teljesítményét. Pozitív tapasztalatok esetén kerülnek képbe a vezetői feladatok ellátására alkalmas emberek. Több intézményben találunk megbízott vezetőket.

Az életpálya-modellt, karriertervezést taglaló kérdést a válaszadók egyrészt az előmeneteli, másrészt a javadalmazási- és ösztönzőrendszer szintjén értelmezték. Egyetlen (13 fös) könyvtárban készül évente karrierterv, és egy nagyobb könyvtárban került kidolgozásra ösztönzőrendszer. További utalásokat találtunk a teljesítményalapú bérezési rendszer alkalmazására, illetve arra, hogy igyekeznek a kollégák bérét a közalkalmazotti bértábla kategóriáihoz képest magasabb szinten tartani. Alapvetóen a karrier fogalma ismeretlen a szakmában, az intézményi elismerések, projektmunkák, munkakörgazdagítás, a képzések, a kompetenciafejlesztés mint motiváló tényező számos alkalommal kerül említésre. Megfogalmazódik, hogy a tapasztalatok szerint a képzésből kikerültek (vagy még képzésben lévők) számára vonzó néhány évet az intézményben tölteni. A könyvtárak megtartó ereje azonban nagyon alacsony: a piacképes kompeten- 
ciák megszerzése után másutt hasznosítják azokat. A válaszadó könyvtárakban az elmúlt két évben közel 28\%-os volt az átlagos fluktuáció, s a távozás oka 63\%ban a munkahelyváltás.

Majdnem minden könyvtárban van tervezett és jól dokumentált teljesítményértékelési rendszer, különböző periodicitással és kidolgozottsággal. A legtöbben könyvtári szinten, a válaszadók 28\%-a az egyetemi teljesítményértékelési rendszerbe csatlakozva minősíti a kollégákat. Ahol még nincs, ott tervezés/ kidolgozás alatt van.

Igyekeztünk képet kapni az intézményi tudásmenedzsmentről is. Jellemző, hogy a képzéseken, szakmai utakon megszerzett tudást a kollégák különbözö formális és informális belső csatornákon megosztják egymás között. A fejlesztési irányokat néhány helyen kompetenciatérkép segíti, illetve a teljesítményértékelésekből kapott erősségek és hiányosságok is alapot képeznek az éves képzési tervhez. A munkacsoportokban való együttdolgozás a mindennapok részévé tette a tudásmegosztást, a jó gyakorlatok megosztását és hasznosítását. A felsőoktatási könyvtárak között az utóbbi időben gyakoribbá/fontosabbá váltak a tudásátadást/tudáshasznosulást célzó szakmai napok, látogatások, workshopok.

\section{Könyvtáros kompetenciák fejlesztési lehetőségei a képzés során - és a kép- zésen túl}

A felmérés során megfogalmazott, valamint a gyakorló egyetemi könyvtárosok javaslata alapján ajánlásokat teszünk a már most is meglévő, de továbbgondolható kompetenciafejlesztő lelehetőségekre. Ezek vonatkozhatnak a képzésben résztvevő, a pályakezdő, a munkahelyet váltó, és minden könyvtárban dolgozó munkatársra is, eszközként használhatják a képzések megtervezői és a gyakorló vezetők is.

Alapvetés a felsőoktatási képzés folyamatos megújítása, új szakirányok indítása rugalmas képzési tervvel. Fontos a gyakorlati tapasztalatokkal rendelkező mestertanárok bevonása, különböző meghívott szakértők részvétele a képzésben, akár gyakorlatvezetőként, akár oktatóként vagy előadóként. A képző intézményeknek nagy hangsúlyt kell fektetniük arra, hogy más szakos hallgatókat be tudjanak vonni az MA- vagy kiegészítő képzésbe, pótolva ezzel az egyszakos képzés által generált tudáshiányt/tudásigényt.

A felsőoktatásban résztvevő könyvtárszakos hallgatók eddig is magas óraszámban vettek részt szakmai gyakorlatotokon. A jó együttmüködés folytatásaként a könyvtárak alkalmazhatják őket diákmunkásként, amely kiterjeszthető más képzéseken résztvevő hallgatókra is. A könyvtárakban terjedő jó gyakorlat, hogy a diákmunkásként alkalmazott hallgatók munkatársakká válnak. 
A változásokra gyorsabban reagálhatnak a kiegészítő, különböző szintủ képzések (pl. OKJ), szakképzések, amelyek folyamatos szervezése és akkreditálása minden, a könyvtári szakmában szereplő képzőintézmény, szervezet feladata.

A képzéseket folyamatosan fejlesztőtréningekkel kell kiegészíteni a legfrissebb ismeretek, és a hiányzó kompetenciák elsajátítása érdekében. Ilyen kompetenciafejlesztő tréningek témája lehet többek között a kommunikációs készség, a tárgyalási készség, a marketing eszközök és módszerek használata, az új technológiai eszközök használata, a vezetői eszköztár bővítése, a tudományos információ kezelése, és bármely új munkaterülethez, a könyvtár stratégiájának megvalósításához szükséges ismeretek, készségek.

A könyvtárak maguk is sokat tehetnek a munkatársak tudásának, kompetenciáinak fejlesztése területén. Kompetenciatérkép készítésével ütköztetni tudják a meglévő és hiányzó kompetenciákat, amely alapján célirányos képzési tervet tudnak készíteni a hiányzó ismeretek és készségek pótlása, fejlesztése érdekében. Az intézményi tudásmenedzsment keretében saját belső forrásaikra is támaszkodhatnak: a meglévő kompetenciákat kiaknázva belső képzések, tudásmegosztó alkalmak szervezésével javíthatják a szervezetben meglévő rejtett tudás hatékony felhasználását.

A tudásmegosztás gyakorlati terepe a csapatmunka, a feladatok munkacsoportokban való elvégzése, ahol a kollégák egymástól tanulva, a feladatok megvalósítása során sajátítanak el új tudást és készségeket, mindezzel hozzájárulva a szervezeti kultúra javításához, fejlesztéséhez, a feladatok hatékonyabb elvégzéséhez is.

A tudásátadás terepe lehet az intézmények közötti együttmüködés és feladatmegosztás, amelyre napjainkban egyre több példát látunk. Nem csupán a szakmai konferenciák, workshopok, de a szakmai szervezetekben folyó együttmüködések is a tudásátadás, tudásmegosztás színterei. A vezetők feladata a munkatársak minél nagyobb létszámú delegálása ezekre a rendezvényekre, szakmai feladatot megvalósító csoportokba. Az itt megszerzett információk megosztását az informális átadási csatornákon való terjesztés helyett formális csatornákra kell terelni, belső innovációs fórumok kialakításával.

A tudásmegosztás újszerủ formája a crowdsourcing, amikor a szervezeten kívüli csoportokat, adott esetben a szolgálandó közönséget, a felhasználóinkat és partnereink különbözö szegmenseit vonjuk be konkrét feladataink, szolgáltatásaink fejlesztésébe, megvalósításába. Ennek jó alkalmazásához is fejlesztenünk kell egy kompetenciát: az egymástól való tanulás képességét.

\section{Rezümé}

A könyvtáraknak évente felül kell vizsgálniuk a stratégiájukat, és alkalmazkodniuk kell az újabb és újabb kihívásokhoz. Vajon a könyvtárosképzés tudja-e követni a felsőok- 
tatási könyvtárak szakemberei iránt támasztott követelményeket? Felvértezettek-e a ma végzett könyvtárosok, rendelkeznek-e a szükséges kompetenciákkal? Elegendö-e a könyvtárosképzés által nyújtott tudás és gyakorlat? Milyen más képzési lehetőségek egészíthetik ki a könyvtárosok felkészültségét, hogy ezen a területen versenyképes tudást tudjanak felmutatni?

A tanulmány összefoglalja a felsőoktatásra és a felsőoktatási könyvtárakra érvényes legfontosabb trendeket, és áttekinti az Egyetemi Könyvtárigazgatók Kollégiuma által végzett, a könyvtárosok kompetenciaigényeiről szóló felmérés eredményeit.

\section{What does an (academic) library require?}

Libraries need to review their strategy annually and adapt to ever changing challenges. Does librarian training meet the requirements of academic libraries for professionals? Are the librarians who graduate today equipped with the necessary knowledge and have the necessary competencies? Is the knowledge and practice provided by librarian training sufficient? What other opportunities are available to complement librarians' training and provide them with competitive knowledge in this field?

The study summarizes the main trends in higher education and academic libraries and reviews the results of a survey of librarians' required competencies conducted by the College of University Library Directors.

KÁLÓCZI KATALIN föigazgató

ELTE Eötvös Loránd Tudományegyetem Egyetemi Könyvtár és Levéltár

ORCID: 0000-0003-0672-2736

KARÁCSONY GYÖNGYI főigazgató

Debreceni Egyetem Egyetemi és Nemzeti Könyvtár ORCID: 0000-0001-6588-743X

KORPÁSNÉ SZÜCS MELINDA osztályvezető

Debreceni Egyetem Egyetemi és Nemzeti Könyvtár ORCID: 0000-0002-6451-2449

HAMZA-VeCSEI TÍMEA hivatalvezetö

Debreceni Egyetem Egyetemi és Nemzeti Könyvtár ORCID: 0000-0002-6812-9244 